\title{
Quality and safety of artisan cheese produced in the serrana region of Santa Catarina ${ }^{1}$
}

\section{Qualidade e inocuidade de queijos artesanais produzidos na região serrana em Santa Catarina}

\author{
Giane Helenita Pontarolo ${ }^{2 *}$; Fernanda Danielle Melo ${ }^{3}$; Caroline Lopes Martini²; \\ Paula Wildemann 3 ; Dileta Regina Moro Alessio ${ }^{3}$; Ricardo Antonio Pilegi \\ Sfaciotte $^{3}$; André Thaler Neto ${ }^{4}$; Eliana Knackfuss Vaz ${ }^{4}$; Sandra Maria Ferraz ${ }^{4}$
}

\begin{abstract}
The serrano artisan cheese produced from raw milk of dairy cattle is a typical product of high-altitude farms in the states of Santa Catarina and Rio Grande do Sul. However, marketing of the cheeses occurs illegally because they lack the minimum maturation period required for cheese produced from raw milk. The production of artisan cheeses is required to follow strict hygiene standards. This study aimed to test the quality and safety of cheeses that were produced in $31 \mathrm{farms}$ of the Serrana region in Santa Catarina after 14 and 28 days of maturation. Coliform count was measured at $35^{\circ} \mathrm{C}$, and presence of other microorganisms such as Escherichia coli, Staphylococcus, Listeria spp., and Salmonella spp. were also tested. Fat and protein percentages, acidity, salt content, and humidity were also evaluated. Data were subjected to statistical analyses using the $\mathrm{SAS}^{\circledR}$ software. After 14 and 28 days of maturation, $74.19 \%$ $(23 / 31)$ and $64.52 \%(20 / 31)$ of samples, respectively, showed higher numbers of coliforms at $35^{\circ} \mathrm{C}$ than those permissible by law. Higher than permissible numbers of $E$. coli were observed in $45.16 \%(14 / 31)$ and $48.39 \%(15 / 31)$ of the samples analyzed after 14 and 28 days of maturation, respectively. Coagulasepositive staphylococci values above $10^{3} \mathrm{CFU} / \mathrm{g}$ were observed in $54.84 \%(17 / 31)$ and $51.61 \%(16 / 31)$ of cheese samples after 14 and 28 days of maturation, respectively. Contamination with Salmonella spp. was not detected. However, Listeria monocytogenes serovar $4 \mathrm{~b}$ was isolated in $3.23 \%(1 / 31)$ and $6.45 \%(2 / 31)$ of samples after 14 and 28 days of maturation, respectively. The results of humidity tests classified the cheese samples into three categories: low, medium, and high humidity. Semi fat cheeses were predominant in both maturation periods, although the samples were classified in thin, semi fat, and fat cheeses. The main variations in the compositions of analyzed samples occurred for salt and acidity levels. The maturation process has not proven to be effective in reducing microbiological contamination to compliance levels. Considering the heterogeneity of the analyzed cheese samples, the frequency of non-conformities with respect to microorganisms and pathogens present in the samples, this study indicates the necessity to improve the Serrano artisan cheese production system through adoption of good manufacturing practice measures.
\end{abstract}

Key words: Escherichia coli. Listeria monocytogenes. Salmonella spp. Coagulase-positive staphylococci. $35^{\circ} \mathrm{C}$ coliforms.

\footnotetext{
1 Parte da Dissertação de Mestrado do primeiro autor.

2 Mestres em Ciência Animal, Centro de Ciências Agroveterinárias, Universidade do Estado de Santa Catarina, UDESC, Lages, SC, Brasil. E-mail: gianepontarolo@hotmail.com; carolinemartinivet@gmail.com

${ }^{3}$ Discentes, Curso de Doutorado do Programa de Pós-Graduação em Ciência Animal, UDESC, Lages, SC, Brasil. E-mail: fernandamelovet@gmail.com; paulawildemann@hotmail.com; alessiodrm@gmail.com; sfaciotti@hotmail.com

${ }^{4}$ Profs., UDESC, Lages, SC, Brasil. E-mail: thaler@cav.udesc.br; eliana@cav.udesc.br; sandra.ferraz@udesc.br

* Author for correspondence
} 


\section{Resumo}

O queijo artesanal serrano, produzido a partir de leite cru de bovinos, é um produto típico dos campos de altitude dos estados de Santa Catarina e do Rio Grande do Sul. No entanto, a sua comercialização na grande maioria ocorre às margens da legislação, por ser fabricado com leite cru e não possuir um período mínimo de maturação. Tendo em vista que a produção de queijos artesanais necessita seguir normas rigorosas de higiene, o presente estudo objetivou desenvolver um diagnóstico da qualidade e inocuidade dos queijos com 14 e 28 dias de maturação produzido em 31 propriedades da Serra Catarinense. Foram realizadas contagens de coliformes a $35^{\circ} \mathrm{C}$, Escherichia coli e Staphylococcus coagulase positiva; pesquisa de Salmonella sp. e Listeria monocytogenes. Os percentuais de gordura, acidez, sal, umidade e proteína também foram avaliados. Os dados foram submetidos as análises estatísticas realizadas no software SAS ${ }^{\circledR}$. Após 14 e 28 dias de maturação, 74,19\% (23/31) e 64,52\% (20/31) das amostras de queijo analisadas, respectivamente, apresentaram limites acima do disposto para coliformes a $35^{\circ} \mathrm{C}$. Contagens de E. coli superiores ao aceitável foram observadas em 45,16\% (14/31) e 48,39\% (15/31) das amostras analisadas após 14 e 28 dias de maturação, respectivamente. Quanto à contagem de Staphylococcus coagulase positiva, 54,84\% (17/31) e 51,61\% (16/31) das amostras de queijos apresentaram após 14 e 28 dias de maturação valores acima de $10^{3} \mathrm{UFC} / \mathrm{g}$. Nenhuma das amostras avaliadas estava contaminada com Salmonella spp., porém Listeria monocytogenes sorovar $4 \mathrm{~b}$ foi isolada em 3,23\% (1/31) e em 6,45\% $(2 / 31)$ das amostras aos 14 e 28 dias de maturação, respectivamente. Em relação à umidade, os queijos foram classificados como de baixa, média e alta umidade. Em relação aos teores de gordura houve a predominância de queijos semigordos nos dois períodos de maturação, embora as amostras tenham sido enquadradas como queijos magros, semigordos e gordos. As principais variações na composição entre as amostras avaliadas ocorreram nos teores de sal e acidez. O processo de maturação não demonstrou ser efetivo na redução de contaminações microbiológicas a níveis de conformidade. A heterogeneidade dos queijos analisados, as frequências de não conformidades em relação a micro-organismos indicadores, e a presença de bactérias patogênicas nas amostras analisadas indicam a necessidade de adequação do sistema de produção do queijo artesanal serrano mediante a profissionalização do produtor e adoção de medidas de boas práticas de fabricação.

Palavras-chave: Coliformes a $35^{\circ} \mathrm{C}$. Escherichia coli. Listeria monocytogenes. Salmonella spp. Staphylococcus coagulase positiva.

\section{Introduction}

In Brazil, cheeses are traditionally produced, usually in small scales, from raw milk by small farmers in various regions of the country. Some examples include the following: Canastra, Salitre, Serro, and Mantiqueira cheeses in Minas Gerais; Colonial and Serrano cheese, in Rio Grande do Sul and Santa Catarina; and Rennet cheese and butter in the northeast (SLOW FOOD, 2012).

Similar to the Serrano artisanal cheese, artisanal cheese produced in Minas Gerais has been marketed illegally for many years because of a law prohibiting the sale of cheeses made from raw milk and matured for a time shorter than 60 days. During this period, several families were seriously affected because they could only sell milk, considering the difficulties in marketing the cheese, which was their main source of income (FRADE, 2013).
In 2013, a normative instruction (NI) signed at the Agriculture Ministry overturned the legislation valid at that time for the sale of cheeses made from raw milk in the state of Minas Gerais, allowing the export of this product to other states. However, they had to comply with health and quality rules, including a monthly analysis of the quality of milk produced, and validation of the product with the seal of the Federal Inspection Service (FIS). In addition, a number of technical and scientific studies estimated the best maturation time of these cheeses between 17-22 days of maturation, depending on the producing region (PEIXOTO, 2013).

The Serrano artisanal cheese (SAC) is a typical product of fields at high altitudes in the states of Santa Catarina and Rio Grande do Sul. Its main feature is its production from raw milk obtained from beef cattle breeds and mixed breeds 
(CÓRDOVA et al., 2011; CRUZ et al., 2008; KRONE; MENASCHE, 2010). The traditional recipe of manufacturing SAC has been perpetuated through several generations without undergoing major changes. The characteristic climate of the region, combined with the traditional techniques used in the manufacture, renders unique physical and organoleptic characteristics to the product, differentiating it from other cheeses produced in the region (CÓRDOVA et al., 2011; CRUZ et al., 2008; KRONE; MENASCHE, 2010).

Although the basic process of cheese manufacture is similar, variations in milk production, technical processing, and maturation time result in a heterogeneous product (KRONE; MENASCHE, 2010; PERRY, 2004). Artisanal cheeses have to follow strict rules of hygiene and quality, because inadequate sanitary conditions of the herd, poor quality control in obtaining and processing the raw material, and improper storage may result in a nonconforming product, leading to risk of infections and intoxications for the consumers (ZAFFARI et al., 2007).

The current rules allow a maturation period of less than 60 days for artisanal cheese from raw milk, if technical and scientific studies prove that the reduction of the maturation period does not compromise the quality and safety of the product (MAPA, 2013). Despite the economic, social, cultural, and historical importance of SAC, its marketing is mostly irregular (CRUZ et al., 2008; MELO et al., 2013). However, Legislative Assembly of Santa Catarina approved a law on August 3, 2016, that regulates the production and sale of SAC, which will allow the product to arrive legally to consumers. The project is now awaiting the sanction of the governor Raimundo Colombo (LEGNAGHI, 2016).

This study aimed to verify the quality and safety of the SAC produced with different maturity periods in farms belonging to the Serrano Artisanal Cheese Producers Association of the State of Santa Catarina.

\section{Material and Methods}

The research was conducted on 31 farms belonging to the Serrano Artisanal Cheese Producers Association of the State of Santa Catarina, in which 62 samples of cheese with 14 and 28 days of maturation were collected.

The cheeses were packaged in craft paper, identified, and packed in insulated boxes for transport to the laboratory of the Microbiological Animal Diagnostic Center (CEDIMA) UDESC in Lages. Microbial contamination was evaluated through quantitative analyses of coliforms $\left(35^{\circ} \mathrm{C}\right)$, Escherichia coli, coagulase-positive staphylococci, Salmonella spp., and Listeria monocytogenes. The samples were also sent to the Food Technology Center of UDESC (NUTA) to determine the percentage of fat, acidity (lactic acid), salt, humidity, and protein, according to Normative Instruction 68 of the Ministry of Agriculture Livestock and Supply (MAPA, 2006). Upon arrival at the laboratory, the cheeses were weighed and the external part was aseptically removed, yielding samples of $25 \mathrm{~g}$ and $10 \mathrm{~g}$ of the internal side of each cheese.

The samples were mixed with $225 \mathrm{~mL}$ of $1 \%$ buffered peptone water (BPW) sterile and $90 \mathrm{~mL}$ of University of Vermont broth (UVM), followed by homogenization using Stomacher ITR for 2 minutes. Dilutions were carried out in tubes containing 9.0 $\mathrm{mL}$ of sterile saline solution $(0.85 \%)$, for testing coliforms at $35^{\circ} \mathrm{C}$, Escherichia coli, and coagulasepositive staphylococci. Immediately after homogenization, the samples were subjected to identification and quantitation protocols described by Silva et al. (2010). Positive controls were maintained in all procedures: L. monocytogenes (ATCC 7644), Salmonella spp. (ATCC 8327), Staphylococcus aureus (ATCC 29213), and E. coli (ATCC 25922).

For identification and quantification of coliforms and Escherichia coli, the Petrifilm ${ }^{\mathrm{TM}}$ system was used, following official method of the Association of Analytical Communities (AOAC) No. 991.14 
(SILVA et al., 2010). The result was obtained by counting the colonies and expressed in $\mathrm{CFU} / \mathrm{g}$.

The identification and quantification of coagulase-positive staphylococci was carried out according to the NI 62 of the Ministry of Agriculture Livestock and Supply (MAPA, 2003). The result was expressed after counting typical colonies.

The Salmonella spp. research was carried out according to International Organization for Standardization 6579:2002 (SILVA et al., 2010). The isolates with biochemical profiles compatible with Salmonella spp. were confirmed by agglutination test with somatic polyvalent serum. The testing of Listeria monocytogenes was carried in accordance with the methodology of the United States Department of Agriculture (SILVA et al., 2010). Strains suggestive of Listeria monocytogenes and Salmonella spp. were sent to the Oswaldo Cruz Foundation (FIOCRUZ) for serotyping.

The results of the microbiological analyses of cheese samples were compared with the reference values of the Technical Regulation on Microbiological Standards for Food, standardized by RDC number 12 of the National Health Surveillance Agency (ANVISA, 2001). Coliforms at $35^{\circ} \mathrm{C}$ and the humidity and fat contents were compared using the Technical Regulations of Identity and Milk Products Quality established by Ordinance number 146 of MAPA (MAPA, 1996).

Data were analyzed using $\mathrm{SAS}^{\circledR}$ software (SAS Institute, 2002). The microbiological variables were transformed to $\log (\log 10)$ to obtain normality. Data were analyzed with descriptive analysis, and for compliance of cheeses, logistic regression was used. The effect of maturation periods in the samples in non-compliance was analyzed using a chi-square test with 5\% significance. Microbiological and physicochemical data of the cheese at 14 and 28 days of maturation were subjected to analysis of variance. For analysis of variance between cheese compositions within the same period of maturation, humidity classes were made according to established parameters for classification of cheeses, in accordance with Ordinance number 146 (MAPA, 1996), and classes in accordance with the lowest or equal to $1 \mathrm{~kg}$ and greater than $1 \mathrm{~kg}$.

\section{Results}

Artisanal cheeses with different maturation periods were classified according to their evaluated fat and humidity. The humidity of the cheese samples was classified as low, medium, and high; medium humidity $(58.06 \% ; 18 / 31)$ prevailed after 14 days of maturation. After 28 days of maturation, cheese samples with medium humidity were $51.61 \%$ (16/31) and those with low humidity were $48.39 \%$ (15/31). Regarding the fat content, semi fat cheeses predominated with $74.19 \%(23 / 31)$ and $90.32 \%$ (28/31) after 14 days and 28 days of maturation, respectively.

The Intermunicipal Consortium of Serra Santa Catarina (CISAMA) approved, through the NI 01 Technical Regulation for Serrano Cheese Identity Fixation (CISAMA, 2014), which characterizes this product with low to medium humidity and semi fat. Thus, according to this norm, only cheese samples after 14 days of maturation showed humidity values outside of this parameter, and with regards to the fat content, there were variations in both periods.

Concerning the physico-chemical composition of cheeses analyzed, the samples showed heterogeneous salt and acidity levels after 14 and 28 days of maturation (Table 1), due to different production systems and hygienic conditions adopted in the farms. 
Table 1. Physico-chemical composition and counts of microorganisms from 31 Serrano artisan cheese samples, matured for 14 and 28 days, collected between April and May 2014 from farms in Santa Catarina state.

\begin{tabular}{|c|c|c|c|c|c|c|}
\hline \multirow{2}{*}{\multicolumn{7}{|c|}{$\begin{array}{cc}\text { Median } & \text { Maximum } \\
\text { Cheese } 14 \text { days }\end{array}$}} \\
\hline & & & & & & \\
\hline Fat $(\%)$ & 19.82 & 28.63 & 28.32 & 45.32 & 5.58 & $\begin{array}{l}\text { Thin: } 10-24.9 \\
\text { Semi fat: } 25-44.9 \\
\text { Fat: } 45-59.9\end{array}$ \\
\hline Protein $(\%)$ & 20.16 & 25.32 & 25.39 & 33.30 & 2.43 & \\
\hline Acidity (\%) & 0.16 & 0.27 & 0.24 & 0.58 & 0.10 & \\
\hline Salt $(\mathrm{NaCl})(\%)$ & 0.52 & 0.87 & 0.75 & 1.81 & 0.31 & \\
\hline Humidity (\%) & 29.86 & 40.59 & 40.95 & 49.88 & 4.73 & $\begin{array}{l}\text { Low: }<36 \\
\text { Medium: } 36-46 \\
\text { High }>46-55\end{array}$ \\
\hline Weight (kg) & 578.00 & 1018.52 & 965.80 & 1867.40 & 303.50 & \\
\hline Coliforms at $35^{\circ} \mathrm{C}(\mathrm{CFU} / \mathrm{g})$ & 0.00 & $4.16 \times 10^{5}$ & $4.30 \times 10^{4}$ & $4.00 \times 10^{6}$ & $8.54 \times 10^{5}$ & $\begin{array}{l}\text { Cutoff: } 10^{3} \\
\text { Low: } 5.00 \times 10^{2}\end{array}$ \\
\hline E. coli $(\mathrm{CFU} / \mathrm{g})$ & 0.00 & $1.57 \times 10^{5}$ & $8.00 \times 10^{2}$ & $2.00 \times 10^{6}$ & $4.28 \times 10^{5}$ & $\begin{array}{l}\text { Medium: } 10^{3} \\
\text { High: } 5.00 \times 10^{3}\end{array}$ \\
\hline $\begin{array}{l}\text { coagulase-positive } \\
\text { staphylococci (CFU/g) }\end{array}$ & 0.00 & $2.03 \times 10^{5}$ & $6.00 \times 10^{3}$ & $2.58 \times 10^{6}$ & $4.98 \times 10^{5}$ & $10^{3}$ \\
\hline \multicolumn{7}{|c|}{ Cheese 28 days } \\
\hline Fat $(\%)$ & 24.35 & 33.47 & 32.29 & 45.32 & 5.21 & $\begin{array}{l}\text { Thin: } 10-24.9 \\
\text { Semi fat: } 25-44.9 \\
\text { Fat: } 45-59.9\end{array}$ \\
\hline Protein (\%) & 22.69 & 26.81 & 26.98 & 34.92 & 2.72 & \\
\hline Acidity $(\%)$ & 0.09 & 0.33 & 0.22 & 0.93 & 0.25 & \\
\hline Salt $(\mathrm{NaCl})(\%)$ & 0.58 & 1.03 & 0.93 & 2.04 & 0.40 & \\
\hline Humidity (\%) & 25.17 & 36.42 & 35.79 & 45.77 & 5.62 & $\begin{array}{l}\text { Low: }<36 \\
\text { Medium: } 36-46 \\
\text { High: }>46-55\end{array}$ \\
\hline Peso $(k g)$ & 360.23 & 990.57 & 914.70 & 1951.30 & 333.38 & \\
\hline Coliforms at $35^{\circ} \mathrm{C}(\mathrm{CFU} / \mathrm{g})$ & 0.00 & $1.42 \times 10^{5}$ & $9.00 \times 10^{3}$ & $2.60 \times 10^{6}$ & $4.90 \times 10^{5}$ & Cutoff: $10^{3}$ \\
\hline E. coli $(\mathrm{CFU} / \mathrm{g})$ & 0.00 & $7.04 \times 10^{4}$ & $4.00 \times 10^{2}$ & $1.00 \times 10^{6}$ & $2.35 \times 10^{5}$ & $\begin{array}{l}\text { Low: } 5.00 \times 10^{2} \\
\text { Medium: } 10^{3} \\
\text { High: } 5.00 \times 10^{3}\end{array}$ \\
\hline $\begin{array}{l}\text { coagulase-positive } \\
\text { staphylococci (CFU/g) }\end{array}$ & 0.0 & $7.11 \times 10^{4}$ & $1.50 \times 10^{3}$ & $1.07 \times 10^{6}$ & $2.19 \times 10^{5}$ & $10^{3}$ \\
\hline
\end{tabular}

Note: 31 samples of each evaluation period were analyzed.

ST: standard deviation

(1) Logarithm of base 10/gram.

${ }^{1}$ lactic acid.

The microbiological parameters established by RDC 12 (ANVISA, 2001) and Decree 146 (MAPA, 1996) and the percentages of non-compliance of the cheeses after different maturation periods are shown in Table 2. Salmonella spp. was absent in the evaluated samples, in accordance with the parameters established by rules (ANVISA, 2001).
However, Listeria monocytogenes serovar $4 \mathrm{~b}$ was isolated in $3.23 \%$ (1) of the samples after 14 days maturation of cheese with medium humidity and $6.45 \%$ (2) of cheese samples with low and medium humidity after 28 days of maturation.

The maturation periods of 14 and 28 days showed no significant reduction in the microbial counts of the 
samples, as compared to the compliance parameters (Table 2). There was a great heterogeneity in the production of cheeses in several parameters: coliform count at $35^{\circ} \mathrm{C}$, fat and protein percentages, as well as humidity between the maturity periods, as shown in Table 1.

Table 2. Frequency of microbiological non-compliances and effect of the maturation period on the coliform count at $35^{\circ} \mathrm{C}$, Escherichia coli, coagulase-positive staphylococci, and the presence of Listeria monocytogenes in 31 Serrano artisan cheese samples that were collected between April and May 2014 in Santa Catarina.

\begin{tabular}{lccc}
\hline \multirow{2}{*}{ Variable } & \multicolumn{2}{c}{ Maturation period } & \\
\cline { 2 - 4 } & \multicolumn{1}{c}{14 days } & 28 days & $\mathrm{P}$ \\
\hline Coliforms at $35^{\circ} \mathrm{C}$ & $74.19 \%(23 / 31)$ & $64.52 \%(20 / 31)$ & $=0.4086$ \\
E. coli & $45.16 \%(14 / 31)$ & $48.39 \%(15 / 31)$ & $=0.7991$ \\
coagulase-positive staphylococci & $54.84 \%(17 / 31)$ & $51.61 \%(16 / 31)$ & $=0.7991$ \\
Listeria monocytogenes & $3.23 \%(1 / 31)$ & $6.45 \%(2 / 31)$ & $=0.5440$ \\
\hline
\end{tabular}

Note: 31 samples of each evaluation period were analyzed.

\section{Discussion}

Lactose present in raw milk is fermented by indigenous lactic acid bacteria with consequent production of lactic acid. Therefore, all microorganisms present in the milk are present in the resultant curd and participate in the biochemical phenomena occurring during cheese maturation (ORDÓÑES et al., 2005; PERRY, 2004). Changes in microflora and contaminations, such as those found in this study with high counts of coliforms at $35{ }^{\circ} \mathrm{C}$, influence the lactic acid concentration, thus interfering in the maturation processes. Acidity has a big influence on the maturation and texture of cheese, and $\mathrm{pH}$ control is important during the manufacturing process, especially in the early days of maturation, to ensure product quality (IDE; BENEDET, 2001).

According to Córdova et al. (2011), in the production of the Serrano artisan cheese, the salt concentration added ranges from $1 \%$ to $5 \%$ per liter of milk. Sodium chloride acts as a preservative in cheese, contributing to the control of growth and microbial activity by reducing water activity (PEREIRA et al., 2014). However, the amount of salt in the cheese used in the study had a mean of $0.87 \%$. This value is relatively low, lacking the potential to inhibit microbial growth. This may possibly be one of the reasons for the high count of microorganisms in the cheese samples.

The maturation periods did not influence the fat, protein, and humidity of the samples. The variations in fat content and other physical and chemical parameters between the samples can be attributed to the heterogeneity in production processes of Serrano artisan cheese. According to Ide e Benedet (2001), heterogeneous humidity percentages are probably an outcome of the variation in temperature and relative humidity in the region, as well as, diversity in the formulation and manufacture of artisan cheeses. Although the basic process of cheese manufacture is similar, variations in the milk sources, processing techniques, and maturation times result in heterogeneous products (PERRY, 2004; KRONE; MENASCHE, 2010). The studies conducted in Serrana region of Santa Catarina by Ide and Benedet (2001) and Melo et al. (2013) confirm the necessity of standardization of production techniques to obtain homogeneous products and acceptable microbiological quality.

The high presence of coliforms at $35{ }^{\circ} \mathrm{C}$ indicates inadequate hygiene and sanitation, show irregularities in hygienic conditions while procuring the milk, and/or manufacture of cheese. In addition, the presence of $E$. coli indicates contamination with 
fecal matter, which can incur serious public health problems (SOUZA, 2006) due to the presence of potentially pathogenic strains. Consistent with the findings of this study, Ide and Benedet (2001) and Visotto et al. (2011) found high levels of coliforms at $45^{\circ} \mathrm{C}$.

Higher counts of coagulase-positive staphylococci indicates contamination during handling and/or obtaining the raw material (SILVA et al., 2010). It is noted that values above $10^{5}$ CFU/g were observed in $25.8 \%$ (8/31) and $16.13 \%$ $(5 / 31)$ of the cheese samples after 14 and 28 days of maturation, respectively. These bacteria could enable the production of enterotoxins if they possess active genes for their production, rendering food improper for consumption. Senger and Bizani (2011) also found Staphylococcus aureus counts that were higher than the maximum values acceptable by law. These results highlight the necessity of greater care and good manufacturing practices for the production of these cheeses.

According to the rules, Listeria monocytogenes should be absent in $25 \mathrm{~g}$ of food (in cheeses with medium, high, and very high humidity), and presence of the same in higher amounts renders the food improper for human consumption due to its risk to consumer health. Thus, quality control in production, on obtaining raw materials and on storage of the samples, should be adopted to prevent contamination of the cheese. Menéndez et al. (2001), Feitosa et al. (2003), and Melo et al. (2013) also isolated Listeria monocytogenes in their studies with cheese samples.

There was a significant reduction in the coliform count at $35{ }^{\circ} \mathrm{C}$ on day 28 day of maturation, but not enough to render the product suitable for consumption (Table 2). In a microbiological study of the Serrano artisan cheese, Melo et al. (2013) found similar results, characterized by the reduction in coliforms at $35{ }^{\circ} \mathrm{C}$ throughout the maturation period. Contrary to our findings, research carried out in the state of Minas Gerais confirmed, through various technical and scientific studies, that 17-22 days of maturation is enough for safe consumption of artisan cheese (FRADE, 2013). It is possible that the differences in the results are due to differences in the original contamination and in maturation conditions.

Analyzing the physical, chemical, and microbiological characteristics of produced artisanal cheeses, allowing appropriate maturation periods, using high quality of the raw material, and following all good practices in the production process would ensure safety and quality of cheese (PEREIRA et al., 2014). Melo et al. (2013) highlights the importance of maturation on qualitative reduction of contaminants and pathogenic microorganisms. Brooks et al. (2012), in a study carried out in the United States, reported 60 days as the minimum period for maturation for cheese from unpasteurized milk to ensure production of microbiologically safe products in that country. The United States legally formalized in 1949, through a federal law, 60 days as the minimum maturation time for cheeses made from raw milk, and this decision affected other countries in Latin America, as well as in Europe, Australia, and New Zealand, which have adopted the same guidelines (CRUZ et al., 2014).

However, according to Perry (2004), because of pressure from the consumers, the producers sell their cheeses after a very short maturation period. In a study of farms that produced the Serrano artisan cheese in Santa Catarina, farmers reported that consumers have a preference for cheese matured between 7-15 days (CÓRDOVA, 2011). Thus, although the NI 30 of MAPA (MAPA, 2013) establishes the reduction of maturation period of artisanal cheeses, it is evident that this should be accompanied with high quality raw material and adoption of good production practices. The maturation process has to be combined with health measures, mastitis control, and best practices, established as mandatory by NI 30 (MAPA, 2013) for effective reduction of the maturation period and obtaining acceptable microbiological levels. 


\section{Conclusion}

Considering the heterogeneity of the examined cheese samples, the frequency of non-conformities in relation to the presence of microorganisms, including pathogenic bacteria, it can be inferred that the maturation periods in this study failed to maintain the levels of contamination in the cheeses at compliance levels. This study suggests the necessity to adapt the production system of Serrano artisanal cheese through adoption of good manufacturing practice measures. Further studies will have to be carried out after the implementation of hygiene procedures to verify the efficiency of maturation in the new conditions of production, which could possibly lead to a lower initial contamination. The law allows reduction of the maturation time through studies, but this study showed that the maturation times used were not sufficient to ensure product safety. Therefore, legal permission should not be granted, until there are changes in the production practices, and new studies are conducted to prove safety of the product.

\section{References}

AGÊNCIANACIONAL DE VIGILÂNCIA SANITÁRIA - ANVISA. Aprova o regulamento técnico sobre padrões microbiológicos para alimentos. Diário Oficial [da] União. Resolução, RDC n.12, de 2 de janeiro de 2001. Brasília, 2001. Disponível em: <http://www.anvisa.gov. br/legis/resol/12_01rdc.htm>. Acesso em: 07 mar. 2014.

BROOKS, J. C.; MARTINEZ, B.; STRATTON, J.; BIANCHINI, A.; KROKSTROM, R.; HUTKINS, R. Survey of raw milk cheeses for microbiological quality and prevalence of foodborne pathogens. Food Microbiology, Illinois, v. 31, n. 2, p. 154-158, 2012.

CONSÓRCIOINTERMUNICIPALDE SANEAMENTO BÁSICO E MEIO AMBIENTE - CISAMA. Aprova o regulamento técnico de identidade e qualidade do queijo artesanal serrano. Instrução normativa n. 01 , de 26 de maio de 2014. Diário oficial dos municípios de Santa Catarina 2014. Florianópolis: CIGA, 2014.

CÓRDOVA, U. A.; PUCCI, A. A.; SCHLICKMANN, A. F. M. B. F.; SCHLICHTING, A. P.; NUNES, I. R.; SOUZA, N. G.; JESUS, N. N.; PEREIRA NETO, S. (Org.). O queijo artesanal serrano nos campos do
Planalto das Araucárias Catarinense. Florianópolis: Epagri, 2011. 122 p.

CRUZ, F. T.; MENASCHE, R. O debate em torno de queijos feitos de leite cru: entre aspectos normativos e a valorização da produção tradicional. Vigilância Sanitária em Debate: Sociedade, Ciência e Tecnologia, Rio de Janeiro, v. 2, n. 4, p. 34-42, 2014.

CRUZ, F. T.; MENASCHE, R.; KRONE, E. E.; WAGNER, S. A. Queijo artesanal serrano dos campos de cima da serra: o saber - fazer tradicional desafiando a qualidade. In: CONGRESO INTERNACIONAL DE LA RED SIAL, 4., 2008, Mar del Plata. Anais... Mar del Plata, 2008. Disponível em: <http://www.ufrgs.br/pgdr/ arquivos/664.pdf>. Acesso em: 9 fev. 2014.

FEITOSA, T.; BORGES, M. de F.; NASSU, R. T.; AZEVEDO, E. H. F. de.; MUNIZ, C. R. Pesquisa de Salmonella sp., Listeria sp., e micro-organismos indicadores higiênicosanitários em queijos produzidos no estado do Rio Grande do Norte. Revista Ciência e Tecnologia de Alimentos, Campinas, v. 23, p. 162-165, 2003. Suplemento.

FRADE, P. A lamentável e incoerente lei que até hoje proíbe a venda do queijo Minas fora do estado. PetitGastrô. Belo Horizonte: Digital Pixel, 2013. Disponível em: <http://www.petitgastro.com.br/alamentavel-e-incoerente-lei-que-ate-hoje-proibe-avenda-do-queijo-minas-fora-do-estado/>. Acesso em: 07 mar. 2014.

IDE， L. P. A.; BENEDET, H. D. Contribuição ao conhecimento do queijo colonial produzido na região serrana de Santa Catarina, Brasil. Ciência e Agrotecnologia, Lavras, v. 25, n. 6, p. 1351-1358, 2001.

KRONE, E. E.; MENASCHE, R. Identidade e cultura nos campos de cima da Serra (RS): práticas, saberes e modos de vida de pecuaristas familiares produtores do queijo serrano. Ateliê Geográfico, Goiânia, v. 4, n. 10, p. $61-85,2010$.

LEGNAGHI, F. Deputados aprovam regulamentação da produção e venda do queijo artesanal serrano. São Joaquim: Agência de notícias, 2016. Disponível em: $<$ http://saojoaquimonline.com.br/2016/08/05/deputadosaprovam-regulamentacao-da-producao-e-venda-doqueijo-serrano/>. Acesso em: 07 dez. 2016.

MELO, F. D.; DALMINA, K. A.; PEREIRA, M. N.; RAMELLA, M. V.; THALER NETO, A.; VAZ, E. K.; FERRAZ, S. M. Avaliação da inocuidade e qualidade microbiológica do queijo artesanal serrano e sua relação com as variáveis físico químicas e o período de maturação. Acta Scientiae Veterinariae, Porto Alegre, v. 41, n. 1152, p. 1-7, 2013. 
MENÉNDEZ, S.; GODINEZ, R.; CENTENO, J. A.; RODRÍGUEZ-OTERO, J. L. Microbiological, chemical and biochemical characteristics of 'Tetilla' raw cowsmilk cheese. Food Microbiology, Illinois, v. 18, n. 2, p. 151-158, 2001.

MINISTÉRIO DA AGRICULTURA, PECUÁRIA E ABASTECIMENTO - MAPA. Permitir que os queijos artesanais tradicionalmente elaborados a partir de leite cru sejam maturados por um período inferior a 60 (sessenta) dias, quando estudos técnico-científicos comprovarem que a redução do período de maturação não compromete a qualidade e a inocuidade do produto. Diário Oficial [da] União, Instrução Normativa n. 30, de 07 de agosto de 2013. Brasília: Departamento imprensa oficial, 2013. Disponível em: <http://www.lex.com.br/ legis_24684623_INSTRUCAO_NORMATIVA_N_30 DE_7_DE_AGOSTO_DE_2013.aspx>. Acesso em: $0 \overline{7}$ mar. 2014 .

. Métodos analíticos oficiais físico-químicos, para

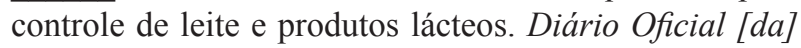
União, Instrução Normativa n. 68, de 12 de dezembro de 2006. Brasília: Departamento imprensa oficial, 2006. Disponível em: <http://extranet.agricultura.gov.br/ sislegis-consulta/consultarLegislacao.do?operacao=visu alizar\&id=17472>. Acesso em: 03 dez. 2013.

. Oficializa os métodos analíticos para análises microbiológicas para controle de produtos de origem animal e água. Diário Oficial [da] União, Instrução normativa n. 62, de 26 de agosto de 2003. Brasília: Departamento imprensa oficial, 2003. Disponível em: $<$ http://extranet.agricultura.gov.br/sislegis-consulta/ consultarLegislacao.do?operacao $=$ visualizar $\&$ $\mathrm{id}=2851>$. Acesso em: 07 mar. 2014.

- Regulamentos Técnicos de Identidade e Qualidade dos Produtos Lácteos. Diário Oficial [da] União, Portaria no 146 de 1996. Brasília: Departamento imprensa oficial, 1996. Disponível em: <http://extranet. agricultura.gov.br/sislegis-consulta/consultarLegislacao. do?operacao $=$ visualizar\&id $=1218>$. Acesso em: 07 mar. 2014.

ORDÓÑES, J. A.; RODRÍGUEZ, M. I. C.; ÁLVAREZ, L. F.; SANZ, M. L. G. S.; MINGUILLÓN, G. D. G. F.; PERALES, L. H.; CORTECERO, M. D. S. Tecnologia de alimentos: alimentos de origem animal. Porto Alegre: Artmed, 2005. $280 \mathrm{p}$.
PEIXOTO, P. Mudança de regra facilita venda de queijo de leite cru entre os estados. Belo Horizonte: Folha de São Paulo. 2013. Disponível em: <http://www1. folha.uol.com.br/comida/2013/08/1322461-mudancade-regra-facilita-venda-de-queijo-de-leite-cru-entreestados.shtml>. Acesso em: 07 mar. 2014.

PEREIRA, B. P.; VIEIRA, T. R.; VALENT, J. Z.; BRUZZA, A.; WAGNER, S. A.; PINTO, A. T.; SCHMIDT, V. Implicações do processo produtivo na qualidade do queijo artesanal serrano. Revista Eletrônica em Gestão, Educação e Tecnologia Ambiental - REGET, Santa Maria, v. 18, p. 116-126, 2014. Edição Especial.

PERRY, K. S. P. Queijos: aspectos químicos, bioquímicos e microbiológicos. Química Nova, São Paulo, v. 27, n. 2, p. 293-300, 2004.

STATISTICAL ANALYSIS SYSTEM INSTITUTE SAS Institute. SAS/STAT. Guide for personal computers. Cary: Editora, 2002. v. 1.

SENGER, A. E. V.; BIZANI, D. Pesquisa de Staphylococcus aureus em queijo minas frescal, produzido de forma artesanal e industrial, comercializado na cidade de Canoas/RS, Brasil. Revista de Ciências Ambientais, Canoas, v. 5, n. 2, p. 25-42, 2011.

SILVA, N.; CHRISTINA, V.; FERRAZ, N.; HIROMI, M.; FRANCISCO, R.; ABELIAR, R. Manual de métodos de análise microbiológica de alimento e água. São Paulo: Varela, 2010. $624 \mathrm{p}$.

SLOW FOOD. Queijos Artesanais de leite cru diversidade, sabor e cultura. Brasil: Slow Food, 2012. Disponível em: $<$ http://www.slowfoodbrasil.com/textos/ queijos-artesanais/521-queijos-artesanais-de-leite-crudiversidade-sabor-e-cultura $>$. Acesso em: 07 mar. 2014.

SOUZA, C. P. de. Segurança alimentar e doenças veiculadas por alimentos: utilização do grupo coliforme como um dos indicadores de qualidade de alimentos. Revista de Atenção Primária a Saúde, Juiz de Fora, v. 9, n. 1, p. 83-88, 2006.

VISOTTO, R. G.; OLIVEIRA, M. A.; PRADO, S. P. T.; BERGAMINI, A. M. M. Queijos Minas Frescal: perfil higiênico - sanitário e avaliação da rotulagem. Revista Instituto Adolfo Lutz, São Paulo, v. 70, n. 1, p. 8-15, 2011.

ZAFFARI, C. B.; MELLO, J. F.; COSTA, M. Qualidade bacteriológica de queijos artesanais comercializados em estradas do litoral norte do Rio Grande do Sul, Brasil. Ciência Rural, Santa Maria, v. 37, n. 3, p. 862-867, 2007. 
